\title{
ROLE PLAY IN BUILDING THE COMMUNICATIVE SKILLS IN STUDENTS FROM ATECHNICAL UNIVERSITY
}

CONTRIBUTJIA JOCULUI DE ROL LA DEZVOLTAREA COMPETENTELOR DE COMUNICARE ALE STUDENTIILOR DINTR-O UNIVERSITATE TEHNICĂ

\section{Elena TIRON}

\author{
Journal of Pedagogy, 2019 (1), 57 - 71 \\ https://doi.org/10.26755/RevPed/2019.1/57
}

The online version of this article can be found at: http://revped.ise.ro/category/2019-en/

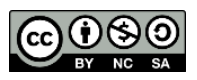

This work is licensed under the Creative Commons Attribution-NonCommercial-ShareAlike 4.0 International License

To view a copy of this license, visit http://creativecommons.org/licenses/by-nc-sa/4.0/ or send a letter to Creative Commons, PO Box 1866, Mountain View, CA 94042, USA.

Published by:

\section{INSTITUTUL DE ȘTIINȚE ALE EDUCAȚIEI}

http://www.ise.ro/

Further information about Revista de Pedagogie - Journal of Pedagogy can be found at:

Editorial Policy: http://revped.ise.ro/editorial-policy/

Author Guidelines: http://revped.ise.ro/the-writer-guide-2/ 


\title{
ROLE PLAY IN BUILDING THE COMMUNICATIVE SKILLS IN STUDENTS FROM A TECHNICAL UNIVERSITY
}

\author{
Elena Tiron* \\ “Gheorghe Asachi” Technical University of Iaşi, \\ Romania \\ Teacher Training Department \\ elenadimitriutiron@gmail.com
}

\begin{abstract}
The article presents a brief history of role play from Moreno's work to the present time and the specificity of role play as a teaching method. The conceptual differences among similar interactive methods are identified: group work, thinking hats, the mosaic method. The didactic method of role play is applied to a group of 90 first-year students from a technical faculty, taking the subject of Communication Techniques, for 12 weeks. The research aims to develop professional communication skills by using role play. We identified the communication problem of the students from a technical faculty, set research objectives, present the research design, the results and their interpretation. The communication problem of the first-year students from a technical faculty consists in the difficulty of dealing with active listening, empathy, negotiation with others. As a result, the research objectives focused on the development of these subcomponents of the communication competences. The criteria for assessing the application of this method for the development of professional communication competences are established by the teacher. Through the SWOT method applied at the end of the 12-weeks research, students highlighted the positive aspects, the negative ones, the opportunities and the risks of implementing role play.

The conclusions of the paper emphasize the need to use interactive methods with the aim of developing students' transversal competences, but also the limitations or inadequacies of these methods.
\end{abstract}

Keywords: professional communication skills, role play, technical higher education, training.

* PhD., Senior Lecturer, “Gheorghe Asachi” Technical University of Iaşi, Romania, Teacher Training Department. 


\section{Rezumat}

Articolul prezintă un scurt istoric al jocului de rol de la Moreno până în prezent şi specificul jocului de rol ca metoda didactică. Se identifică diferen ierile conceptuale intre metode interactive asemănătoare: lucrul pe grupe, pălăriile gânditoare, metoda mozaic.

Metoda didactică a jocului de rol este aplicată pe un lot de 90 de studen i de la o facultate tehnică, din anul I, la disciplina Tehnici de comunicare, timp de 12 săptămâni.

Cercetarea îşi propune să analizeze impactul aplicării jocului de rol asupra dezvoltării competen elor de comunicare profesională.

Demersul de cercetare eviden iat în articol a pornit de la problema de comunicare a studen ilor din anul I de la ofacultate tehnică, ce constă în dificultatea rela ionării prin ascultare activă, empatie, negociere cu ceilal $i$. Ca urmare, obiectivele cercetării s-au concentrat pe dezvoltarea acestor subcomponente ale competen ei de comunicare. Se stabilesc de către profesor criteriile de evaluare a aplicării acestei metode pentru dezvoltarea competen ei de comunicare profesională.

Prin metoda SWOT aplicată la sfârşitul cercetării de 12 săptămâni, studen ii au pus în eviden $\breve{a}$ aspectele pozitive, pe cele negative, oportunită ile şi riscurile aplicării jocului de rol.

Concluziile lucrării subliniază necesitatea folosirii metodelor interactive cu scopul dezvoltării competen elor transversale ale studen ilor, dar şi limitele sau inadecvările acestor metode.

Cuvinte-cheie: antrenament, competen e de comunicare profesională, joc de rol, învă ământ superior tehnic.

\section{Brief history of role play}

Role and role play appeared with the ancient theatre ( $5^{\text {th }}$ century, BC) keeping its main function of catharsis or emotional purification (Aristotle) so far. The audience laughed, screamed, whistled, applauded at the ancient performances thus releasing their emotional tension with the aim of curing their passions. The role theory and the role play method with cognitive functions, and moreover socio-affective, therapeutic and organizational functions have been resumed in modern science and research. One of the most important representatives of psychosociology, who founded a new science, "Sociometry", with new concepts and methods, was J. L. Moreno. Moreno's multidimensional preparation, in mathematics, medicine and philosophy, provided him with a complex and creative vision of the inter- 
human relationships that form the core of the nucleus of group formation. The diverse cultural environments in which he lived and worked in Bucharest, Vienna, New York favoured the discovery of the positive and creative potential of the conflict. Thus Moreno, starting from improvisational theatre, develops two new methods of inter-human conflict management, problem solving and groups reconstruction which he names: psychodrama and socio-drama. These methods consist in applying role theory and role play, either individually or in groups, to identify and solve intrapersonal or interpersonal conflicts that block or disrupt the natural and creative evolution of the person or group. Moreno critically reported to Freud and the artificial, office environment of the Freudian research compared to the natural environments in which he discovered the role of conflict in personality reconstruction. Morelian psychodrama and sociodrama have a broad applicability: therapeutic, pedagogical, organizational, leading to the formation of new individual and group competencies. These methods are well-organized by selecting the protagonist, the group, by describing the characters, choosing the themes that reflect the main actor's conflicts. The dramatic play consists in the protagonist's monologue, his dialogue with his alter egos, the conversation with the psychotherapist or the group according to the spontaneity laws, and, finally, the dismantling of the fossilized roles and the building of new roles. The structure and cathartic functions of this morenian dramatic game resembles in a decisive way the ones of the ancient Greek theatre.

In the view of the Romanian Psychodrama Association, sociodrama is considered as a method of active exploration in society, organizations and communities to enforce, where it is appropriate, individual or group changes/ developments / transformations.

"A sociodrama session has three primary goals: a better understanding of the situation from a social point of view, a clearer perception of the participants about their roles and the roles of others in relation to that situation (explored in the sociodrama session), an emotional release or catharsis as the participants express their emotions about the subject." (Wiener, 1997).

The association for classic psychodrama quotes Ken Sprague, who, in 1998, shows that "sociodrama is a method of education. It gives us the opportunity 
to use our imagination to practice life situations in the sociodrama group, even making mistakes for which we could be punished if we do them in our daily lives. The sociodrama method provides group training for collective actions and education." (Sprague, 1998).

In this vision, as training and education methods, we use the didactic sociodrama with the specific aspect of role playing.

\section{Role play as a teaching method}

Why the game?

Game is a method of biologically proven development, present in all animal species, it is a method of learning verified by our species, it is spontaneous, it is based on pleasure, it comes from the player's interest, it is active and dynamic, stimulating and offering satisfaction, unleashes the creative potential of the conflict, is not evaluative or critical, is a good way to solve conflicts. Education has gradually taken over and developed the natural valences of the game by transforming them into the didactic method.

In order to become a method, it is necessary to meet the requirements of a teaching- method:

1. to be a way of knowing, acquiring knowledge for students;

2. to allow the development of skills, abilities, didactic competences for students;

3. to be appropriate for the pupils/students age;

4. to be organized in time and space appropriate to the needs of students/ appropriate to educational context;

5. to have specific, clearly and explicitly designed educational objectives;

6. to correspond to didactically and legally approved teaching curricula;

7. to have verified results, verifiable by other actors on the stage;

8. to be correlated with similar or different educational methods;

9. to be accepted by pupils/students;

10. to be pleasant, stimulating, engaging, but also efficient.

In the didactic activity, we found a predominant use of the didactic game in the lower grades. Hence, we ask ourselves whether the didactic game is 
applicable only at younger ages to primary/secondary school or it is also applicable to students in the higher grades as well.

If the specific conditions for a didactic method are met, we consider that role play can also be applied at older ages: high school and college, in collaboration with other methods, with specific objectives, contents, and techniques.

\section{Conceptual differences}

Role play is part of the category of interactive, participatory methods with all their features but, at the same time, having its own specificity.

Among the classifications of these methods (Muchielli, 1982; Bocoş, 2002; Cerghit, 2003, 2007; Oprea 2003, 2006, 2009; Negre -Dobridor, I., Pânişoară, I. O, 2005), we selected:

a) Interactive teaching and learning methods in group: the reciprocal teaching/learning method (Palinscar), the mosaic method (Jigsaw), comprehensive reading, "Cascade" method, the method of learning in small groups ("STAD -Student Teams Achievement Division"), TGTTeams/Games/Tournaments method, the "Share-Pair Circles" method, the "Pyramid" method, dramatized learning.

b) Methods of knowledge acquisition and systematization and verification: cognitive/conceptual map, "cognitive chains", "fish skeleton", the cause and effect diagram, "spiderweb", "water lily flower" technique, "light-up cards".

c) Problem-solving methods by stimulating creativity: brainstorming, "starburst", thinking hats method, "carousel", "multi-voting", "the round table”, group interview, case study, "critical Incident”, "Phillips 66”, "technique 6/3/5”, “creative Controversy”, “aquarium” technique, "four corners", "Frisco" method, sinectica, "buzz groups".

For all the methods in this classification (Tiron, Buju, Tufeanu, Stanciu, 
2017, p. 19), we identified the principle of play: cognitive, socio-emotional, behavioural, creative. The game and the game method can be used as teaching-learning-evaluation methods or procedures for the fixing and consolidation of knowledge, as techniques, methods or procedures for stimulating creativity. The roles that pupils/students perform are summarizers, solvers, experts, critics, leaders, idea generators, emotional, creators, observers, participants, those who describe, compare, associate, analyse, argue, apply, draw, deduce, explain.

In the literature, it is important to differentiate, although it is not essential, between role-playing and simulation, the latter being more complex. The simulation category includes didactic play, dramatized learning, opponent learning, learning on simulators. Simulation games are considered ways of training to fulfil roles in real social life. They can be games, arbitrage games, prediction games, negotiation games, etc. Role play is an active-participatory method that can fulfil all the functions of a teaching method in teaching, learning, assessment. Role play can also be used in all types of lessons: acquiring knowledge, developing new skills abilities. The pupils/students form new types of behaviours need to understand and influence interaction partners.

Role play has the following advantages:

- addresses the entire personality on a cognitive, socio-affective, behavioral, mobilizes and trains students to action and interaction;

- is implicit in other active methods: problem-solving, group work, heuristic conversation;

- primarily contributes to the training and development of those behaviours and attitudes less targeted by other methods: effective self-control, group management, spontaneity, intrapersonal and interpersonal communication, creativity;

- offers the possibility of correcting incorrect or incomplete behaviours in certain role situations.

So, we ask ourselves: why is this method not used frequently?

The role play method has the limitations of interactive methods in a predominantly traditional education:

- the preparation, design and conclusion are time consuming; 
- emotional blockages may occur in the application and interpretation of roles, but these also represent a surplus of knowledge for the pupils/ students/teachers involved;

- if it is not well prepared, role play can easily be devalued and then it can be harder to resume;

- require specific but complementary skills for theatre and directing for teachers.

Role play must have clear objectives, formulated in action terms achievable in one lesson or more, one chapter (benchmarks), until the learning of the specific role to a particular social or professional status.

Didactic role play also has well-established stages that increase the effectiveness of the proposed and developed objectives. These stages are:

1. the identification of the educational professional or social situation which is suitable for simulation using role playing;

2. the modelling of the situation and the design of the scenario by retaining the essential aspects that establish an interactive model;

3. the selection of the partners and training them on the specifics and requirements of role play, using role cards;

4. the individual learning of the role by each participant by studying the card;

5. the acting of the roles;

6. individual and group reflection on the game experience, debating with all participants on acting and replaying sequences in which the group has not achieved the expected behaviours.

The observers can also participate in the debate. It is necessary for interpreters to be given priority to communicate what they have felt.

The conditions of effective role play can neither be ignored:

1. the method should be familiar to pupils/students through similar exercises and debates on roles;

2. choosing roles should take into account the preferences of the participants;

3. it is important to avoid or resolve emotional blockages of the group leader or of the teacher; 
4. it is important to monitor the evolution of the participants in order to highlight certain positive or negative aspects of the roles.

Specialized literature (Cerghit, 2007) presents several types of role-playing games with a wide range of possibilities for applying to educational subjects, for example:

- The game of representing structures refers to the simulation of activity in enterprises, institutions, firms that contribute to understanding the functioning of these organizational structures, to the learning of new statuses and roles.

- Decision making is the one in which decision-making activities are simulated in which pupils/students learn to make decisions, depending on the objectives, the specifics of the activity, the possible effects of these decisions.

- The arbitration game can be used in certain interpersonal and institutional conflictual situations; the participants are playing the roles of those involved in the situation and learning the role of arbiter in resolving a conflict.

- The competition game simulates competition in any field, in a school, in a company, economically, socio-culturally, in sports. The competition can be between two or more people, inter-individual or group competition. The roles, the ways to resolve a competition of the types victory-victory, victory-defeat, defeat-defeat are explained and played taking turns.

- The negotiation game - it simulates negotiation in any field with special reference to specific educational subjects or to professional, financial, banking, sales, commercial, or other social activities where negotiation is involved.

For education, are indicated those games role arising from the issue of age, group and individual characteristics of pupils/students or conflict situations through which they pass.

\section{Description of the research}

The research was applied on a target group of 90 first-year students of the Faculty of Civil Engineering, "Gheorghe Asachi” Technical University in 
Iaşi, attending the Communication Techniques class, for 12 weeks, first academic year 2018-2019, 1st semester.

Researched problem is the inadequate development of communication skills of students of technical profiles. The motivation of this research was due to the difficulty that students have in active listening, empathetic socializing and negotiation observed in the first 2 weeks of the semester.

In terms of the Common European Framework of Reference for Languages (2007), the student's or user's general individual skills are mainly based on knowledge (savoirs), skills (savoir-faire) and existential competence (savoir-être) that he or she possesses, and on his/hers ability to learn (savoir-apprendre). In this view, we can define the communication competences as a set of suitable and efficient knowledge, abilities, attitudes and behaviours regarding:

a. social positions as transmitter or receiver of communication (writing, reading, listening);

b. communication functions: cognitive, emotional, behavioural (understanding, expressivity, decision, action);

c. types of communication: verbal, nonverbal and paraverbal and their efficient use;

d. learning, correction, creation in communication.

In the structure of the communication competences, these elements do not have the same degree of development and representation, they are different depending on the participants to communication and the communicative situation. In the dynamics of the communication phenomenon, we encounter the following aspects: native (linguistic intelligence) and acquired/ formed/ corrected/ invented (language).

The Communication Techniques course, first semester, in the curriculum of a technical faculty is two hours long weekly course and targets the following contents: meanings and axioms of communication, types and forms of communication, communication functions, professional communication, institutional communication crisis. Out of the specific objectives of the discipline, we retain for our research: applying the verbal, nonverbal, paraverbal, oral, written, individual, group, interpersonal, mass, educational 
and professional communication techniques in specific domains and the psychological foundation of student behaviour for the engineering profession.

The objectives of our research have been correlated with the objectives of the course but are designed according to the research principles as follows:

1. identifying communication sub-skills that can be trained by applying the simulation game, of the construction engineer role-status;

2. participation of all students (90) to at least 4 role plays;

3. increasing student satisfaction in the application of this method;

4. determining the degree of realization of the communication subcomponents perceived by each student.

Communication sub-competencies from a psychological and pedagogical point of view that were evaluated through research were:

- accepting a new role;

- the relationship with the other, within the role;

- empathy towards the other, by mentally assuming the role of the other;

- active listening;

- cooperation in the context of the role, through the application of negotiation techniques;

- tolerance towards participants in the communication situation;

- flexibility in solving the conflictual situation;

- spontaneity in playing the game;

- expressivity in verbal communication, consistent with non-verbal communication;

- role and script creativity.

The methods used in the research are: brainstorming to identify the difficulties of communication, role play involving poor communication skills and SWOT analysis to evaluate the results obtained after the training of students during the course.

The students were trained for 12 weeks (course and seminar) about the social positions of the transmitter and receiver, in all communication functions: cognitive, affective, volitive, behavioural, in all types of communication situations: verbal, non-verbal, paraverbal. They were stimulated to elaborate scenarios of those role games, in which to involve 
construction companies and employers' roles, employees, employment commission, designers, designers, inspectors. They were allowed to choose their roles and we worked with them in writing the scenarios. We detected huge group emulation, an engaging, active, cheerful, positive, collaborative and problem-solving environment, great flexibility in scenario development and conflict resolution.

Students perception of the degree of realization of the communication subcomponent skills was checked after each role-play by granting a grade of 10 - the maximum level of the sub-component embodiment to 5 - the minimum level. These grades were compared with the teacher's grades for the achievement of communication sub-components. Finally, the average of these grades was made.

Table no. 1. The degree of achievement of the communication subcomponents

\begin{tabular}{|c|c|}
\hline $\begin{array}{l}\text { SUBCOMPONENTS OF COMMUNICATION } \\
\text { COMPETENCE }\end{array}$ & AVERAGE \\
\hline 1. accepting a new role & 8.55 \\
\hline 2. relating with the other in the role & 7.41 \\
\hline $\begin{array}{l}\text { 3. empathy towards the other, by mentally } \\
\text { assuming the role of the other }\end{array}$ & 7.42 \\
\hline 4. active listening & 7.74 \\
\hline $\begin{array}{l}\text { 5. co-operation in the context of the role by } \\
\text { applying negotiating techniques }\end{array}$ & 7.23 \\
\hline $\begin{array}{l}\text { 6. tolerance towards participants to the } \\
\text { communication situation }\end{array}$ & 7.43 \\
\hline 7. flexibility in solving the conflict situation & 7.32 \\
\hline 8. spontaneity in playing the game & 7.14 \\
\hline $\begin{array}{l}\text { 9. expressivity in verbal communication } \\
\text { consistent with non-verbal communication }\end{array}$ & 7.05 \\
\hline 10. role and script creativity & 7.19 \\
\hline
\end{tabular}


As a method of self-knowledge and knowing pupils/students (Stănculescu, 2008) SWOT method was applied in our research to evaluate the role-play method. Therefore, students have listed, after the completion of training in communication, strengths, weaknesses, opportunities and threats that they experienced in the method of role play.

\section{The SWOT analysis}

At the end of the research, students completed the four quadrants of the SWOT table and centralizing assessments has highlighted these aspects of the method of role play to develop communication skills.

Strengths: development of communication skills, training, positive climate, trust, dynamism, collaboration.

Weaknesses: emotional blockage, low self-esteem, conflicts in solving the role.

Opportunities: role play cannot be applied to all educational disciplines in any didactic situation but only to certain disciplines, in some situations that have been described here. In conclusion, in a class such as "Communication techniques", role play offers a great opportunity for training and psychosocial development.

Threats: the students have also discovered some relationship difficulties or complexes that cannot be solved by the role play method alone. But once discovered, these problems can be addressed later by other methods including therapeutic ones.

\section{Interpretation of results}

Intermediate grades were obtained, between 8.55 and 7.05. The best results were obtained for accepting the role, active listening and tolerance towards other participants subcomponents. The lowest results were obtained in expressivity, spontaneity and role-creativity. 
For the three subcomponents for which the students obtained smaller grades, more training is needed, especially for role creativity, both in terms of the scenario developed by them and the proper application of the scenario. The students' self-evaluation was realistic, being very close to the teacher's evaluation. Therefore, the degree of satisfaction of the students in achieving these components was very high.

As far as the research objectives are concerned:

- objective 1: identifying the communication subcomponents that can be trained through role play, was entirely accomplished by using the brainstorming method;

- objective 2: 78 of the 90 students participated in at least 4 role-playing;

- objective 3: the high degree of satisfaction among students resulted from their positive, high self-evaluation;

- objective 4: was achieved by engaging the 10 subcomponents of communication by all the participating students.

\section{Conclusions}

a. Applying role play by simulating a professional role-status, in our case future construction engineer, was a new method for the students, different from the methods they know from the technical specialty disciplines.

b. The novelty of the method and the fostering of a pleasant, secure, dynamic social-emotional climate stimulated participation in teaching activities, enthusiasm to engage into and learn new roles.

c. The students' own perception of the achievement of the communication subcomponents was verified by the teacher's perception. The similar the two marks were, the more conclusive the results.

d. The sub-components of psychological and pedagogical communication were achieved in a proportion of $100 \%$ with different values but similar to each other.

e. Applying interactive methods especially to technical students is an effective way to stimulate, learn, acquire, consolidate, and evaluate knowledge. 


\section{References}

- Aristotel (1998). Poetica. Bucureşti: Editura IRI.

- Bocoş, M. (2002). Instruire interactivă. Repere pentru reflec ie şi ac iune. Cluj-Napoca: Editura Presa Universitară Clujeană.

- Cerghit, I. (2003). Sisteme de instruire alternative şi complementare. Structuri, stiluri, strategii. Bucureşti: Editura Aramis.

- Cerghit, I. (2007). Metode de învă ământ, Ed. a IV-a. Iaşi: Editura Polirom.

- Goullier, Fr. (2007). Le Cadre européen commun de référence pour les langues (CECR) et l'élaboration de politiques linguistiques: défis et responsabilités. Strasbourg.

- Karp, M., Holmes, P., \& Tauvon, K. B. (Eds.). (1998). The handbook of psychodrama (K. Sprague, Illustrator). Florence, KY, US: Taylor \& Frances/ Routledge.

- Moreno, J. L. (1953). Who Shall Survive? Foundations of Sociometry, Group Psychotherapy and Sociodrama. Beacon House.

- Muchielli, R. (1982). Metode active în pedagogia adul ilor. Bucureşti: Editura Didactică şi Pedagogică.

- Oprea, C. L. (2003). Pedagogie. Alternative metodologice interactive. Bucureşti: Editura Universită ii din Bucureşti.

- Oprea, C. L. (2006). Strategii didactice interactive. Bucureşti: Editura Didactică şi Pedagogică.

- Oprea, C. L. (2009). Strategii didactice interactive, Ed. a IV-a. Bucureşti: Editura Didactică şi Pedagogică, R.A..

- Palincsar, A.S. (1986). Reciprocal teaching. In: Teaching reading as thinking. Oak Brook, IL: North Central Regional Educational Laboratory.

- Pânişoară, I. O. (2008). Comunicarea eficientă. Iaşi: Editura Polirom.

- Spolin, V. (1986), Theater Games for the Classroom. Northwestern University Press.

- Stănculescu, E. (2008). Psihologia educa iei, de la teorie la practică. Bucureşti: Editura Universitară.

- Tiron, E., Stanciu T., Buju, S., \& Tufeanu, M. (2017). Cum să devină studen ii la inginerie şi arhitectură mai interactivi şi mai creativi? Răspund profesorii lor. Iaşi: Editura Politehnium.

- Wiener, R. (1997). Creative Training: Sociodrama and Team Building. Bristol, PA, Jessica Kingley.

- www.psihodramaclasica.ro 
The online version of this article can be found at: http://revped.ise.ro/category/2019-en/

\section{(CC) $B Y-N C-S A$}

This work is licensed under the Creative Commons Attribution-NonCommercial-ShareAlike 4.0 International License.

To view a copy of this license, visit http://creativecommons.org/licenses/by-nc-sa/4.0/ or send a letter to Creative Commons, PO Box 1866, Mountain View, CA 94042, USA.
Versiunea online a acestui articol poate fi găsită la: http://revped.ise.ro/category/2019-ro/

\section{(cc) BV-NC-SA}

Această lucrare este licen iată sub Creative Commons Attribution-NonCommercial-ShareAlike 4.0 International License.

Pentru a vedea o copie a acestei licen e, vizita $i$ http://creativecommons.org/licenses/by-nc-sa/4.0/ sau trimite i o scrisoare către Creative Commons, PO Box 1866, Mountain View, CA 94042, SUA. 